\title{
RED CORPSES: A MICROHISTORY OF MASS GRAVES, DEAD BODIES, AND THEIR PUBLIC USES ${ }^{\star * *}$
}

\author{
François-Xavier Nérard \\ Université Paris 1 Pantheon-Sorbonne, CRHS - SIRICE, \\ Paris, France
}

What happens to corpses produced by armed conflicts? This question may seem simple: most bodies are buried, more or less quickly, in mass graves. However, the time between death and the moment when the human remains are inhumed deserves to be studied. This article focuses on the situation in the Urals at the end of the Civil War (1918-1919). The fights between the Bolsheviks and their opponents resulted in many casualties. The Bolsheviks gave a fundamental, and rather unusual, importance to the bodies of 'their' dead and attached a specific political significance to them. They developed a politics of corpses, using them in public space to assert their power. The bodies of dead Red fighters were brought back to symbolic places, resulting in impressive public funerals across the city of Yekaterinburg in 1918. Their burial sites became contested territories, protected by the authorities but derided by their opponents. After their final victory in 1919, Bolsheviks displayed their dead as proof of the cost of their struggle. Mutilated bodies were shown to carry the stigmata of sacrifice. The inventory and identification of victims became a central and immediate requirement. Inquiry commissions questioned witnesses and looked for mass burials and abandoned corpses. Mass graves were searched, cadavers exhumed and made visible. The public use of corpses was, however, not limited to identification purposes. The display of dead bodies, which is not unusual in Orthodox culture, took on a special political dimension. There was mass dissemination of the sight of death through these public monuments and the use of photography. We must especially stress the topographical importance of the displayed death: the exhumed bodies were used to tell of victory, to make control of the territory explicit. The memorialisation of some mass graves completed the process. In Yekaterinburg, but also in more distant localities, monuments were erected. They were meant to materialise the sacrifice of so-called 'communards' and the peculiar place of the Civil War in the

* I would like to thank Evgeny Burdenkov and Konstantin Bugrov for their very appreciated help in finding certain materials for this article.

** Citation: Nérard, F.-X. (2021). Red Corpses: A Microhistory of Mass Graves, Dead Bodies, and Their Public Uses. In Quaestio Rossica. Vol. 9, № 1. P. 138-154. DOI 10.15826/qr.2021.1.570.

Цитирование: Nérard F.-X. Red Corpses: A Microhistory of Mass Graves, Dead Bodies, and Their Public Uses // Quaestio Rossica. Vol. 9. 2021. № 1. P. 138-154. DOI 10.15826/qr.2021.1.570.

(C) Nérard F.-X., 2021

Quaestio Rossica • Vol. 9 • 2021 • № 1, p. 138-154 
narrative of the new Bolshevik regime, honouring the memory of the dead and mobilising the living.

Keywords: death studies, mass graves, civil war, Urals

Что делать с телами убитых во время вооруженного конфликта? Этот вопрос может показаться простым: большинство их более или менее быстро закопают в массовых захоронениях. Однако время между смертью и моментом погребения останков не всегда совпадает. Данная статья посвящена ситуации на Урале в период Гражданской войны (1918-1919). Бои между большевиками и их противниками привели к многочисленным жертвам. Большевики придавали фундаментальное и довольно необычное политическое значение телам «своих» погибших. Они разработали настоящую политику в отношении их тел, используя их в публичном пространстве для утверждения своей власти. Тела погибших красных привозились в символические места, что привело к впечатляющим общественным похоронам в Екатеринбурге в 1918 г. Их места захоронения стали оспариваемыми территориями, охраняемыми властями, но высмеиваемыми противниками. После окончательной победы в 1919 г. большевики выставили своих погибших в качестве доказательства цены своей борьбы. Искалеченные тела были показаны как стигматы их жертвоприношения. Составление списков и идентификация жертв стали центральным и непосредственным требованием новой власти. Следственные комиссии допрашивали свидетелей, искали массовые захоронения и брошенные тела. Однако их использование не ограничивалось целью идентификации. Их показ (в определенном смысле принятый в православной культуре) получил беспрецедентное распространение в общественном пространстве посредством этих публичных акций и использования фотографий. Таким образом мертвые тела приобрели особое политическое измерение. Особо следует подчеркнуть топографическое значение таких акций: эксгумированные трупы использовались для того, чтобы рассказать о победе, сделать явным контроль над территорией. Увековечивание памяти о некоторых массовых захоронениях завершило этот процесс. Не только в Екатеринбурге, но и в более отдаленных местах были установлены памятники и переименованы улицы. Они должны были материализовать самопожертвование тех, кого в повествовании о новом большевистском режиме называли коммунарами, и стать своеобразными сакральными местами Гражданской войны.

Ключевые слова: исследования смерти, массовые захоронения, Гражданская война, Урал

"Bare your head, workers of the Urals! Today we honour the bright memory of the Ural communards who fell in the struggle for the triumph of the Workers' and Peasants' Revolution!" ${ }^{1}$ On 3 August 1919, Ural'skiy Rabochiy, the newspaper of the Yekaterinburg Communist Party regional

\footnotetext{
${ }^{1}$ The Russian texts were translated by the author.
} 
committee, resumed publication. A fortnight had passed since 15 July when the city was liberated as the Whites were forced to withdraw. The Bolshevik daily was still a modest paper of two pages, but nevertheless chose to devote the "first word of the born-again paper" to the martyrs of the revolution, to those who fell for victory. The whole issue was made up of articles singing the praises of activists and fighters like Ivan Malyshev, shot by the enemies of the Bolsheviks in June 1918, Leonid Vainer, who died during the fighting a month later, and Yakov Sverdlov, one of the main actors in the revolution in the Urals who died in Moscow from the Spanish flu on 16 March 1919. A poem, published on page two in a black frame, draws our attention. It is an old text with a new title, 1918-1919. Formerly Requiem, it had been written by Liodor Palmin in 1865 and was popular in militant circles:

Не плачьте над трупами павших борцов,
Погибших с оружьем в руках,
Не пойте над ними надгробных стихов,
Слезой не скверните их прах.
Не нужно ни гимнов, ни слез мертвецам,
Отдайте им лучший почет:
Шагайте без страха по мертвым телам,
Несите их знамя вперед!
С врагом их, под знаменем тех же идей
Ведите их бой до конца!
Нет почести лучшей, нет тризны святей
Для тени, достойной борца! ${ }^{2}$

[Искра, 1865, № 11].

Unusually, although bluntly, this poem deals with corpses and their materiality. "Walk without fear over the dead bodies", the poet suggests, using the cadavers as material (not symbolic) support to "carry forward" the flag and the cause of the revolution. The image is striking, especially in an issue devoted to the glorification of fallen comrades.

There was no shortage of corpses during the Russian Civil War in gen$\mathrm{eral}^{3}$ and in the Urals in 1919 in particular [Вебер, c. 105]. What was to be

${ }^{2}$ Don't mourn over the corpses of dead fighters,

Dead with a gun in their hands,

Don't read them funeral verses,

Don't spoil their remains with your tears

Corpses don't need hymns or tears,

Pay a better tribute to them,

Walk without fear over the dead bodies

Carry forward their flag.

Against their enemies, with the flag of their ideas

Fight until the end!

There is no better tribute, no funeral meal that would be more sacred

For the shadow of the dignified fighter!

${ }^{3}$ The overall human cost for the Civil War in the former Russian Empire is difficult to establish. Jonathan Smele gives an estimate of 10 million victims of military actions, excluding 5 million victims of the famine [Smele, p. 3]. 
done with them? The opposition between Antigone and Diogenes has often helped us to question practices with regards to corpses. Thomas Laqueur begins his essential work on the uses of mortal remains by citing the cynical philosopher answering the question about what should be done with his body after his death: "Throw it over the walls so that it is devoured by birds and beasts" [Laqueur, p. 1]. Antigone had exactly the opposite attitude. She chose to pay respect to her brother's remains at the cost of her own life. In times of peace, the respect due to remains is crucial. Attitudes to dead bodies were, however, dramatically affected by the war. The large number of dead made the usual rituals more difficult to perform. Most were hastily buried in mass graves. Urgency sometimes provoked the disturbing uses of corpses: Ivan Strod, a Red officer, recalled in his memoirs how he used his comrades' frozen corpses to build a barricade in the heart of Yakutia when he was besieged by White rebels [Строд, с. 133-134]. Antigone's standards did not seem capable of standing up to the necessities of war.

Therefore, the publication of Palmin's poem seems to confirm that the Diogenes paradigm was prevalent. It illustrates a choice to assert the pre-eminence of life over death, of the living over the dead. Is this, however, truly accurate? Were Bolshevik practices during the Civil War limited to the symbolic celebration of heroes and the pragmatic neglect of their material bodies? What happened to the corpses of the Reds who died in the Civil War? What role was assigned to them? What meaning? Limiting this study to Bolshevik practices will allow it to encompass a larger chronological scope because they won the war and mastered the space and the narrative. While a lot of literature has already been written on symbolic celebrations of the dead, this article aims rather to deal with the material and physical presence of dead bodies during the civil war. I will argue that the attitude to bodies and mass graves in the Urals was structured around two fundamental periods, before and after July 1919, when the Bolsheviks secured their victory. Following Emmanuel Fureix, the period from 1918 to 1919 could be called a "necrophile time", redefining "the relationship between the living and the dead, and the expression of mourning, right down to the treatment of the corpse and its fragments, [allowing] new public and political gestures or rituals to emerge" [Fureix, p. 23]. I will study the new public uses of corpses, their significations and the changes brought about by victory. After 1920, corpses disappeared physically and symbolically from Soviet public space, changing fundamentally the practices of commemoration.

\section{Uncertain Times of Struggle}

From October 1917 to July 1919, Bolshevik positions were very fragile in the Urals, as in most of the country. Their authority was quickly weakened and contested as they came up against armed opposition and popular insurrections. Support faded rapidly: for example, the historian Mikhail Veber mentions that there were four times fewer communists in Izhevsk at the end of May 1918 than at the beginning of April (1700 and 400, respectively) [Вебер, c. 46]. In Orenburg region, a Cossack rebellion led by Ataman Alek- 
sandr Dutov ${ }^{4}$ began gaining momentum from January 1918 onwards, although the Bolsheviks repelled rebel assaults twice, in January and in March. The rebellion of the Czech and Slovak legionnaires in Chelyabinsk on 14 May 1918 further complicated the situation. The need to mobilise new soldiers led the Bolsheviks to often use force, which provoked increased hostility from the population. The Bolsheviks therefore had to face both local riots, sometimes violent, and armed insurrections (in Kurgan, Shadrinsk, Perm, and Yekaterinburg). In July 1918, both Orenburg and Yekaterinburg fell to the anti-Bolshevik forces. This marked the end of this period, when pressure was very high on the new masters of the country. Effective control of space and power was a question of life or death, especially in Yekaterinburg, the city where, by the end of April, the tsar's family was kept as prisoners. Surprisingly, funerals and the display of fallen Red fighters were part of these efforts.

The public use of dead bodies during wars is not unusual. However, it is often the body of the enemy that is shown as proof of victory. This was often the case in colonial wars, leading sometimes to gruesome practices [Arzel, Foliard]. Showing one's own dead is less common. Certainly, the workers' movement had a long history of celebrating the vanquished [Traverso], therefore paying special attention to death and its commemoration. It is therefore even more interesting to study what happened in Yekaterinburg in 1918. Twice, at the end of January and at the beginning of April, the bodies of Red fighters who had died in the fights against Dutov were shown and buried with pomp in the city. Both ceremonies constituted more than political mourning: the Bolshevik "politics of corpses" [Fureix, p. 48-59] was literally meant to "tame" public space, which was far from being under firm control. These demonstrations were made of people, sounds, and colours: each element was part of filling urban space, as one discovers when reading the idealised account of the ceremonies in Ural'skiy Rabochiy [Уральский рабочий, 1918, 17 февр., с. 2; Там же, 1918, 7 апр., с. 2].

First of all, crowds were mobilised. On 31 January, according to some estimates, there were "thousands" of participants, although the exact number is difficult to assess ${ }^{5}$. The journalist mentions, however, only, "a small group of relatives". The majority of attendees were thus activists or soldiers, supporters and manifestations of Soviet power in all its diversity. This visual effect was enhanced by the relatively long route of the cortege, chosen in order to be seen by as many people possible. From the former train station in the north of Yekaterinburg, the coffins, wrapped in red fabric, were moved through half of the city to the municipal soviet ${ }^{6}$ (on Pokrovsky Ave.) and then back to Cathedral Square.

The square was central and symbolic for the old regime. It drew its name from the eighteenth-century Theophany church, one of the city's

\footnotetext{
${ }^{4}$ To learn more about the head of the Cossacks in Orenburg region, see: [Ганин].

${ }^{5}$ A postcard reproducing a photograph from the funerals published by the Ural Regional Museum of Revolution shows hundreds of people, not thousands.

${ }^{6}$ Former mansion of the millionaire Alphonse Fomič Poklevskij-Kozell.
} 


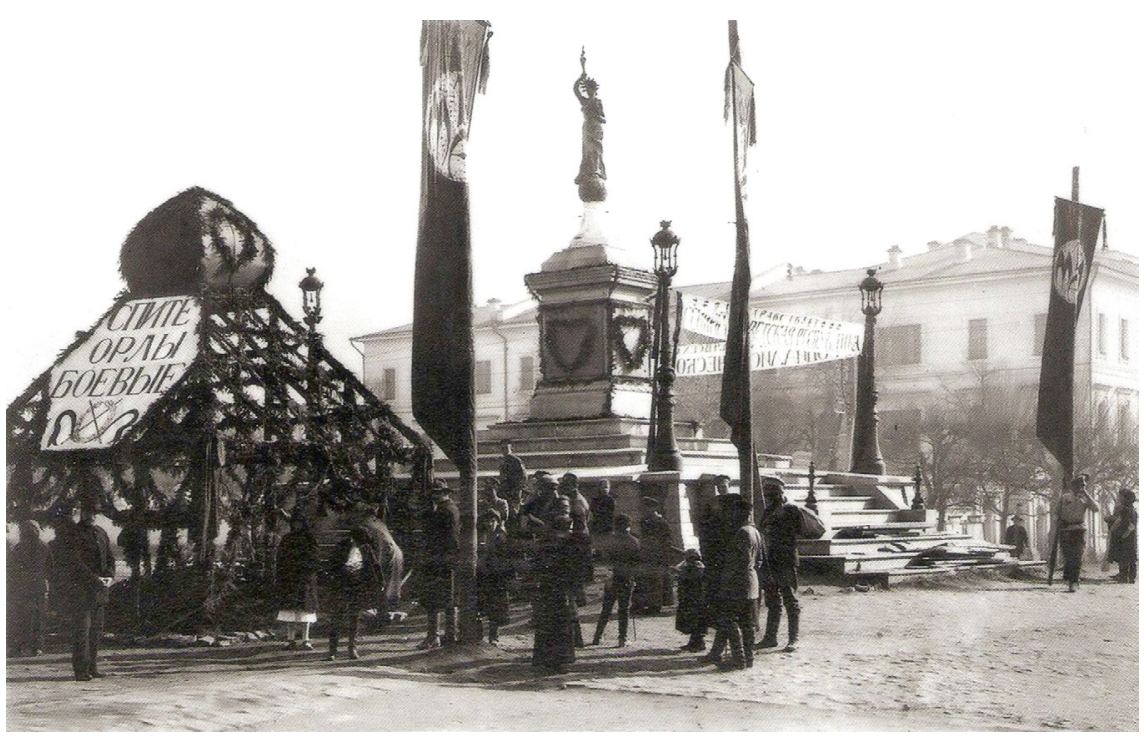

1. The Statue of Liberty and the memorial complex. Yekaterinburg. 1918

religious landmarks. It was also marked by a monument to Alexander II (built in 1906), which was pulled down during the February Revolution. It was therefore significant for the new authorities to organise the burial precisely on this site. The cortege came to an end at the pedestal of the former monument to Alexander II: "the wreaths are laid on the grave, on the steps of the pedestal, on which not so long ago proudly towered over the square the figure of the tsar, symbol of the old regime" [Уральский рабочий, 1918, 17 февр., с. 2]. This funeral tactic conveys a sense of revenge, as does the mass grave dug in the immediate vicinity of the former monument. The new heroes were not former rulers but fallen red soldiers.

This material occupation of space was complemented by visual elements displaying colours and political symbols. Each political group had its own flags [Znamensky, Gallice]. At that time, the political arena was still relatively pluralist: present were the Soviet of worker and soldier delegates, the sailors of the Gangut fighting in Orenburg, young socialists, the Left SR, the Ural Association of Anarchists, trade union organisations (printers, tailors, tanners or mill workers). The red of socialism and the black of mourning were visible on the route across the city.

The occupation of space had also an aural dimension. An orchestra accompanied the procession throughout, playing funeral marches. After the coffins were laid in the grave, some soldiers, former comrades of the dead, fired a salvo, followed by the crowd shouting "Hurrah!" in honour of the fallen. Speeches were delivered, once again demonstrating the diversity of organisations present. The sounds included the silence of mourning and the pattering of earth thrown onto the coffins by the participants. The story told by the Bolshevik press is one of courage and martial vir- 
tue, where weakness and despair had no place. The mourning is regarded as a display of strength.

The unity of the revolutionary forces was key to understanding this demonstration of strength, while funerals were a kind of synecdoche. The dead soldiers, the part, represented sacrifice for the Revolution, the whole. Their actual bodies were not significant, they were not really displayed. All four of them were buried in a collective grave. Their names were written in the newspaper, but they were mostly referred to as "comrade Red soldiers", an indistinct formula. Moreover, as the historian Evgeny Burdenkov demonstrates, there is no certainty that this information was accurate. The individualisation of death, a process well described for early nineteenth-century France by Emmanuel Fureix, is not the point here [Fureix, p. 50]. On the contrary, the message conveyed was one of unity and cohesion. On the grave, a temporary monument was erected but bore no names, only a verse (Sleep Combat Eagles) from a poem written by Konstantin Olenin ${ }^{7}$ in memory of the soldiers of the Russo-Japanese War, which became a popular song with music by Ivan Kornilov 8 .

This symbolic demonstration of force was meant to mask, or to compensate for, the fragility of the Bolshevik hold on the city. We should not forget that at the end of January 1918, the October Revolution was barely three months old. An article published two days later by the very same Ural'skiy Rabochiy and signed by "Berezovski" reveals, in an outraged tone, how the Bolshevik presence in Yekaterinburg was contested.

Even though it is not its aim, this paper makes it possible to get a better understanding of what happened during the funerals. First of all, the context was far more tense than one might think. The city was abuzz with rumours: according to them, it was not four bodies that were to be brought back to the city, but four carriages of corpses. The synecdoche that the Bolsheviks were trying to use was turned against them: the four corpses were not part of the Revolution, but part of the greater loss. The Bolshevik writer was concerned about the risk of panic and anxiety among "the wives, sisters and mothers" of soldiers sent to Orenburg. Even the place where the four were buried and the ceremony itself were turned upside down by the rumour-mongers. Why such honours when most of the dead were "buried hastily on the front in on-site mass graves"? The very symbolic dimension of the ceremony was thus undermined. Rumours circulated even among the crowd on Cathedral Square. "Berezovski" gives the impression of fearing a potential coup from the soldiers of the $124^{\text {th }}$ reserve infantry regiment. He reports a rumour that he supposedly personally heard in the square, according to which soldiers were going to come and shoot all the people present [Уральский рабочий, 1918, 19 февр., с. 1].

\footnotetext{
${ }^{7}$ During the Civil War, Olenin fought for the Whites.

${ }^{8}$ These words were quite common on military monuments.
} 


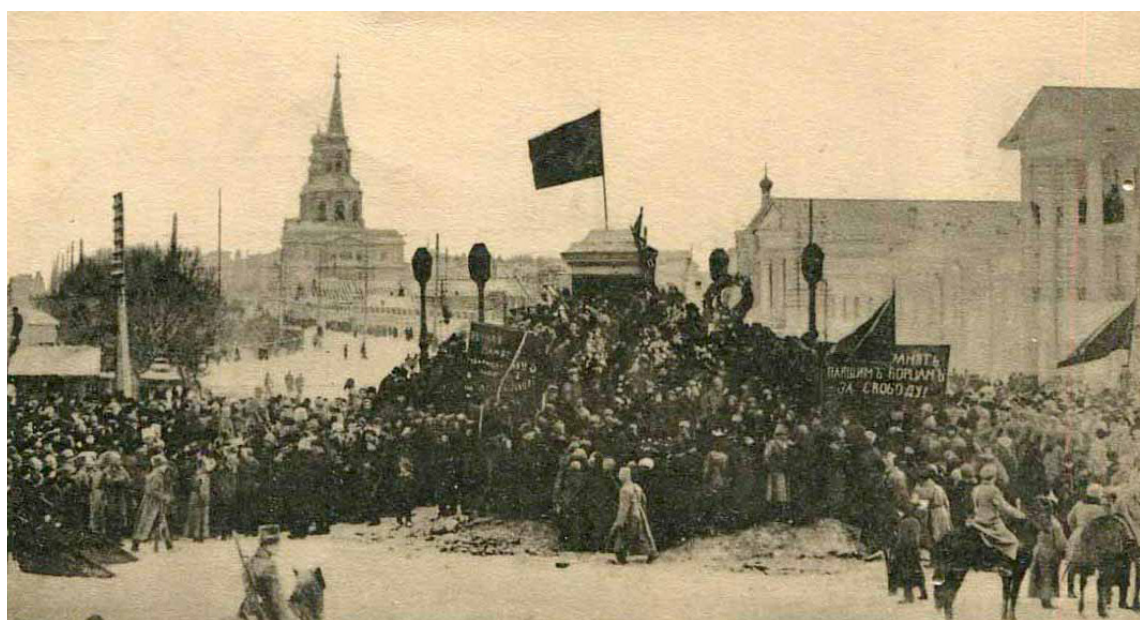

2. The funeral of the first victims from Dutov's front. Yekaterinburg. 1918

Downgrading words of dissent or hostility to "rumours" might have been a strategy of the paper. It seeks to give the impression that opponents were forced into hiding, compelled to use "weapons of the weak" [Scott]. The reality might have been more nuanced, as the journalist himself seems to actually take the threat seriously. He asks "the soldiers from the $124^{\text {th }}$ regiment not to allow any bastard to discredit revolutionary honour" and to "publicly deny any hint of armed rebellion." The presence of contestation at the very heart of the commemoration is emphasised even more by another detail told by the journalist. Just after the funerals, a "dame from 'society" snapped at the participants from her carriage: "They are obviously telling you that they are fighting for liberty, but they are carrying guns and even machine guns: what kind of liberty is this?" She receives answers and finally leaves, but the very fact that she felt strong enough to yell at the crowd during a supposedly important event is highly significant. The Bolshevik hold was not that firm: the pomp of the ceremony was therefore far more than a mere commemoration. The honours given to the corpses were a way to materially inscribe the relatively new Bolshevik order into the space of the city. But this was not enough, as anti-Bolshevik city dwellers fully understood this strategy: in the following days, the mass grave on Cathedral Square was frequently desecrated. According to the descriptions of the banker Vladimir Petrovitch Anichkov, in memoirs written in the US after his emigration, such incidents were common: the grave was opened and "filled with discharge sewage", decorations substituted with a "dead cat or dog", and epitaphs replaced by "swear words of three or five letters" [Аничков, с. 158-159].

A few weeks later, renewed fighting against Dutov's Cossacks took place not far away from Troitsk, south of Chelyabinsk. On 5 April, the bodies of

\footnotetext{
${ }^{9}$ Usually studied for Stalin’s era: [Johnston; Слухи в России XIX-XX веков].
} 
nine killed workers were brought back to the city and buried two days later [Уральский рабочий, 1918, 27 апр., с. 2]. The ceremony was pretty much the same: a cortege moving from the train station to the burial site, the colours of flags, the sounds of salvoes fired from rifles and revolvers, the music of a funeral march sung by the participants, the cadence of speeches. The only difference lay in the fact that the bodies were apparently buried in individual graves (the press spoke of mogily, plural), and not in the centre of the city but in front of their former factory, Verkh-Iset Zavod (VIZ). The territorial dimension of the funerals was still important: symbolic places were bolshevized. The choice of a factory on the periphery rather than the central city square is nevertheless significant: the show of force was, probably, less crucial than in January. Once again, single individuals faded in front of a more political representation of sacrifice for the future. "Rest in peace, your names will live forever in the memory of the workers of Yekaterinburg", wrote a journalist from Ural'skiy Rabochiy, only mentioning, however, a single surname. The bodies and funerals were definitely more political than material.

These efforts meant to appropriate city space found their post-factum justification a few months later. On 25 July, the White Army took control of Yekaterinburg. One of the first things they did was to erase the mass graves. Vladimir Anichkov described the extreme excitement of the crowd gathering around the pedestal: "Someone was haranguing the crowd and demanded that the bodies of the scoundrels be dug up and the monument restored. The crowd applauded wildly" [Аничков, c. 159]. The corpses were exhumed the next night and reburied in an unknown place at the order of the new commandant of the city. The same thing happened to the graves in front of the VIZ factory. Red corpses disappeared as Bolshevik power vanished.

They were immediately replaced by victims of the Bolshevik terror. In the very same square, the bodies of 19 intelligenty and burzhui were honoured in the cathedral. Remembering the event, Anichkov mentions the size of the crowd, "a sea of heads", the colours of the flowers on the coffins, but also, as it was summer, an "unbearable smell" 10 that forced him to leave. The meaning of these funerals seems, however, significantly different, more classical. The religious dimension is essential here. This is Antigone's ambition: not to leave the bodies of martyrs without rites. The same practice can be found in the town of Kasli in September 1918 after the forced departure of the Bolsheviks. The bodies of several opponents ${ }^{11}$ who had been shot and thrown into mine pits were exhumed, together with 37 other victims ${ }^{12}$ [Власть народа, 1918, 1 сент., с. 3], and brought back with a procession to the city centre: they were buried on the grounds of the Cathedral of the Ascension.

\footnotetext{
${ }^{10}$ One of the dead was Aleksandr Ivanovich Fadeev, a mining engineer executed by the Cheka on 26 June, one month prior. His body must have been been decaying.

${ }^{11}$ More particularly, the priests Borodintsev, Belaev, and Miropolski.

${ }^{12}$ On the events of Kasli, see: [Вебер, c. 106-108].
} 


\section{The Underpinning of Bolshevik Power}

The Bolsheviks regained control of Yekaterinburg on 15 July 1919. Only five days later, the first burials of "heroic fighters who died for the liberation of proletariat" took place [Музей истории Екатеринбурга. Ед. хр. 1075] ${ }^{13}$. City dwellers were called ("all to the funerals, all outside, death to the White Guard!") to take part in a demonstration bringing the corpses from the city hospital to the square in front of the Verkh-Iset factory. The meaning of this moment was, however, very different from those that took place in 1918, as close as they might have seemed. The materiality of the corpses this time played a central role. Aleksandr Medvedev ${ }^{14}$ described the ceremony and his feelings in his memoirs: ${ }^{15}$

Next to the dug mass grave, on a platform there were open coffins, with mutilated, shredded bodies. It was impossible to recognise my comrades who I had met and spoken to every day [Медведев, 1960, с. 138].

Another, less edited, version of the text is even more explicit:

In front of the mass grave on the platform there was a series of coffins upholstered in red cloth. The coffins were not closed. In these bodies, mutilated, chopped and streaked with ramrods, it was difficult to recognise those I had known well, I had met every day... but in one of the coffins bright red curls shone, not yet touched by decay. Was it really Sasha Smanovsky? $\langle\ldots\rangle$ And here's another... The face cannot be recognised, not a face, but a wound... Black braids, a brown gymnasium dress... Ripa... Ripa Polezhaeva... [Медведев, 1964, c. 189-190].

Showing mutilated corpses was a political act. The materiality of wounds, the stigmata they displayed were part of the discourse of sacrifice and victory ${ }^{16}$. Death itself was not enough anymore: it was the way in which death occurred that mattered, above all its materiality.

Other remains were exposed in Bolshevik-controlled territories. Between February and May, the Bolsheviks ran a campaign against the cult of relics in the central part of Russia under their control [Nérard, 2014; Smith]. They decided to expose saints' relics from numerous churches and monasteries in order to demonstrate the inanity of beliefs about the bodies of saints. According to tradition, the corpses of dead saints were supposed to stay intact, untouched by natural decay. Shrines containing holy relics were thus publicly opened by the new authorities, revealing bones and not

${ }^{13}$ Thanks to E. Burdenkov for providing this source.

${ }^{14}$ A young Red army soldier, a worker at the VIZ and a future worker at the Uralmash Plant.

${ }^{15} \mathrm{He}$ recalls the ceremony at $3 \mathrm{pm}$, while the aforementioned poster mentions time around $4 \mathrm{pm}$. There were several editions of these memoirs. The first was published in Sverdlovsk in 1939.

${ }^{16}$ The same practice can be found in Tomsk in January 1920 when the Bolsheviks reburied their dead in Cathedral Square after the liberation of the city [Nérard, 2017, p. 79]. 
corpses. For the Bolsheviks, this campaign was a way to show the rest of the population that they were the new masters and that they were fearless. They were able to do what they wanted, to break any taboo, to defy even God's law. Photographs and even films of Bolsheviks surrounding open shrines were common. The near coincidence of the timing was not accidental, even if no text makes an explicit comparison between both practices. Both uses of open coffins were a way for the Bolsheviks to display their strength. The Bolshevik dead were the exact opposite of relics. They were real people, material bodies decaying after their death, stinking. They were human heroes who had died for the sake of the revolution. Dead bodies in public spaces were thus among the symbolic foundations on which the Bolsheviks built their power and legitimacy.

This politics of corpses also had another dimension. At the beginning of August, the Bolsheviks, faithful epigones of Antigone, set off in search of their dead in zones abandoned by the Whites in order to honour them. Collecting testimonies, they located massacre sites and mass graves, exhumed the corpses trying to identify them, and called relatives if needed. These operations were publicised: according to the Bolsheviks, the Whites had written a "book of blood and horrors" [Уральский рабочий, 1919, 6 авг., с. 3] that had to be made known. Readers of Ural'skiy Rabochiy could find a new, almost daily, section called "along the bloody trails", where the crimes of the defeated opponents were exposed and the fate of their victims very vividly told with extensive use of names. Very thorough inquiries were made: hundreds of pages were filled with data on the victims of the White terror or those "under the command of Kolchak" [ГАСО. Ф. P-511. Оп. 1. Д. 82, 235]. The authorities tried to learn exactly who had been killed and why.

The desire to name dead fighters is not new. It has even been reinforced by the characteristics of modern wars, where "individuals were swallowed up by mass death", as Reinhart Koselleck points it [Koselleck, p. 155]. The American Civil War and the First World War marked the first attempts to identify soldiers with individual plaques or documents. This did not prevent the anonymisation of death, a major consequence of the scale and technique of slaughter: millions of corpses are difficult to identify and modern weapons tend to destroy the integrity of bodies. Part of the answer can be found in the installation of monuments to the "fallen soldier" or to the "soldat inconnu" in Paris. The age of necronominalism, described by Thomas Laqueur, is the other side of the same coin [Laqueur, p. 414-446]. Names were a way to ward off the prospect of a lonely and nameless death. A civil war, where the victims are not necessarily regular fighters, reinforces that necessity of nomination.

Corpses were central in these processes of identification, as exhumations took place only a few weeks after the massacres, when the bodies were still recognisable. On 12 August, such mass graves were revealed in the region of Kamyshlov, some $130 \mathrm{~km}$ east of Yekaterinburg [Уральский рабочий, 1919, 12 авг., с. 2]. During their July 1919 retreat, the Whites took some 
150 prisoners from the local prison as they headed along the Siberian road to Tyumen. But this huge number of prisoners slowed them and they decided to get rid of them, killing most of them on the spot. The massacre did not remain a secret due to the testimonies of those who had escaped the slaughter. An inquiry commission was rapidly set up, probably on 1 August, to find the corpses. It was headed by Khokryakov, a communist and member of the Kamyshlov revolutionary committee. The commission exhumed the bodies from the mass grave on 6 August [ЦДООСО. Ф. 41. Оп. 1. Д. 126. Л. 114].

The minutes of the exhumation allow us to describe what happened and to understand the aims of the Bolsheviks. This was a very political moment. The exhumation was mostly conducted by grassroots activists: beside Khokhryakov, there were Meskidov, mentioned as a member of the commission, two presidents of rural revolutionary committees, and Suklesish, head of the volost revolutionary committee of Nikolski. The only professional linked with medicine was Zuev, a nurse practitioner from Kamyshlov hospital, far from a forensic specialist.

We carried out excavations, medical examinations, and burials of comrades, former captives in Kamyshlov and other prisons, victims of the evacuation to Siberia of the White Guard gangs, mercenaries of capitalists and here is what happened: there was a grave with 90 corpses, at the fifth kilometre of the Siberian road from the village of Nikolsky towards the village of Chereshnisky, three sazhen' (six metres) off the roadside. Not far from this grave, one person was buried in one grave and three people in the other. All these corpses were taken from the graves for examination and photography and placed in the middle of the road; after washing the corpses and undressing them, medical examination and examination by relatives started in order to identify them, and the following corpses were recognised... [ЦДООСО. Ф. 41. Оп. 1. Д. 126. Л. 114].

126 corpses were found in different graves. Only a small minority were identified by relatives ( 28 out of 90 in the former example). Even fewer were claimed by their families. The others were reburied on the same site. There was clearly something more to the whole operation than identifying and honouring the dead. The display of the washed corpses alongside the road does not seem to be merely technical. Corpses were photographed. Each body was meticulously described (height, sex, estimated age), especially with regards to the wounds. Most of them had been inflicted with bladed weapons (sabre or bayonet) although some had bullet wounds. The bodies were horribly mutilated: skulls were chopped, chests and limbs stabbed. For example:

Citizen Matvei Konstantinovich Cheremnykh, aged 53, from Nikolskaya volost and factory, head smashed, right arm cut off from the shoulder at a length of 20 centimetres, two wounds on the right leg, bullet wound in the back on the right, height 2 arshin 6 vershok ( $1 \mathrm{~m} \mathrm{70).}$ 
This politics of bodies was a way of demonstrating sacrifice. This was not only an Antigone-style approach, aimed at paying due tribute to the dead, or a Diogenes-style one, not really caring about the material side of things, but a third way where the corporality of corpses was central: they were a powerful embodiment of sacrifice. They became therefore not an immaterial symbol, but a concrete incarnation of victory. This is why they had to have a name, to be shown and seen.

\section{Times of Memorialisation and Disappearance}

Corpses soon disappeared, however, for obvious and natural reasons: they were reburied and turned to dust. A new era began, one no less political but with a different materiality: the era of memorialisation. Bones and flesh were replaced by stone and metal. Red victims were now names on monuments. A link was, however, preserved with the former politics of corpses, as the sites of mass graves were often chosen as the focus of memorialisation.

Monuments were built relatively rapidly. One of them was inaugurated in Yekaterinburg on 1 May 1920, not far from the VIZ factory, where some bodies had been re-inhumed. Others could be found across the region: in Revda ${ }^{17}$ (1922), Nizhny Ufaley (1924), Verkhny Ufaley, Lysva (1924), and Sysert. In Kamyshlov, a modest pyramid was built in 1924 [Камышловские известия, 2018, 26 июля, с. 4]. As in the new regional capital, however, the monuments were built on the sites of former mass graves. In the city of Kasli, as well as in Nizhny Ufaley, the victims of the Kolchak army were buried in front of a factory entrance, where a new statue was erected in 1922. It represented a young fighter, dressed in a worker's apron, holding a rifle and a hammer: it was dedicated "to the heroes fallen for the revolution, 1918-1922". This monument was pretty much standard and can be found elsewhere in the region. The new monuments also had another aim. In most of these little factory towns, there were mass graves created by the Bolsheviks after anti-Bolshevik rebellions. The new monuments and the new mass graves were also meant to conceal the traces of Bolshevik violence, to once again mark the territory.

However, this change in materiality proved difficult to manage, as commemoration during reconstruction was not a priority ${ }^{18}$. After the Civil War, Soviet people were looking more to the future than to the past. Monuments were built but failed to fully capture the interest of the population. They were what Pierre Nora has called "dominant lieux de mémoire", places ordered "from above" that "one attends rather than visits" [Nora, p. 23]. In Yekaterinburg, the monument itself was changed several times: at first, it was a globe topped by a naked woman holding a flag and

${ }^{17}$ In Revda, the tsarist repression of worker protests in the first half of the nineteenth century was commemorated: the dedication was therefore dated 1841-1922.

${ }^{18}$ See the way mass graves in Leningrad were neglected before the establishment of Piskarevo cemetery [El Kenz, Nérard, p. 197-214]. 
a slogan "to the Ural communards fallen for liberation..." But, maybe because of the naked figure, the monument was rapidly removed and replaced with a cast-iron hero, a symbolic proletarian defeating tsarism. The site nevertheless was neglected as the memory of the Civil War faded away. In May 1924, an anonymous correspondent ("Old Guard") of Ural'skiy Rabochiy wrote a short article denouncing the state of the mass graves: there were no flowers and the surfaces of some had collapsed due to a phenomenon connected with the decay of corpses: "The graves of the fighters for the proletarian revolution cannot be forgotten" [Уральский рабочий, 1924, 25 мая, с. 5]. Such articles can also be found in 1927. However, the authorities made every effort to ensure the permanence of commemoration: several new versions of the monument were inaugurated until a final version was erected in 1959, a work by the architects Yu. Potapov and B. Izmodenov.

The monument's continual evolution ended up masking the grave itself. When, in 2015, excavations were conducted due to the forthcoming world football championship, nothing was found: according to documents from the party archive, up to 200 bodies were supposed to be buried there. The remains may have been removed during the reconstruction of the memorial in 1959. This disappearance is more than symbolic: what is left of the memory of the Civil War? The monument is today surrounded on both sides by busy roads, making access anything but simple.

The Bolsheviks had to answer a very practical question during a murderous war. What was to be done with the corpses of fallen fighters? In most places, dead bodies were buried where they were killed, in anonymous mass graves. But the Bolsheviks did not content themselves with that. They developed a real politics of corpses, using dead bodies in public space. Some of them were carried through public space to deal with different demands. During the tense and fragile atmosphere of 19171918, the Bolsheviks felt a need to demonstrate their strength given that they were actually weak and threatened. Fallen soldiers were displayed across the city with pomp, music, and flags. Monuments were erected. But all this proved fragile: their monuments were mocked, their dead ignored and promptly reburied as soon as they lost the control of the city.

When their grip on power tightened after 1919, they still used a political grammar based on corpses, although different from the previous iteration. Corpses had to be shown in all their ugliness in order to emphasise the violence of the Whites and the scale of the sacrifice for the revolution. Wounds and mutilated bodies became the stigmata of the new authorities. The population had to see the price paid for victory.

Bodies, however, eventually disappeared for natural reasons. On the site of mass graves, monuments were erected. They were meant to become landmarks in the mental landscape of city dwellers. But as time passed, the memory of the Civil War became blurred. During the 1920s, people 
wanted to go forward and forget about the horrors of war. These monuments were sometimes forgotten even though the political authorities always maintained them. The materiality, however, faded away, as the population did not seem to appropriate the monuments. They still exist, but most of their necessity has disappeared.

The materiality of corpses was crucial. It was a tool in the foundation of a new society. Knowing this, it is difficult not to think about what happened less than 20 years later during Stalin's Great Terror, a core element of which was precisely the total disappearance of bodies. The victims of repression were arrested and then disappeared. Relatives were not informed of their deaths; they were even lied to and consequently were deprived of the bodies. Stalin and his henchmen had probably learned the lesson of the naked year Pilnyak mentions and the political power of corpses.

\section{Список литературы}

Аничков В. П. Екатеринбург - Владивосток (1917-1922). М. : Рус. путь, 1998. 364 с. Вебер М. И. Антибольшевистское повстанчество на Урале в годы Гражданской войны (1918-1919) : дис. ... канд. ист. наук. Екатеринбург : [Б. и.], 2014. 309 с.

Власть народа. 1918. 1 сент.

Ганин А. В. Атаман А. И. Дутов. М. : Центрполиграф, 2006. 622 с.

ГАСО. Ф. Р-511. Оп. 1. Д. 82, 235.

Искра. 1865. № 11.

Камышловские известия. 2018. 26 июля.

Медведев А. И. По долинам и по взгорьям. М. : Воениздат, 1960. 152 р.

Медведев А. И. По долинам и по взгорьям. Свердловск : Сред.-Урал. книж. изд-во, 1964. $219 \mathrm{c}$.

Музей истории Екатеринбурга. Ед. хр. 1075.

Слухи в России XIX-XX веков. Неофициальная коммуникация и «крутые повороты» российской истории. Челябинск : Каменный пояс, 2011. 362 с.

Строд И. Я. В якутской тайге. М. : Воениздат, 1961. 185 с.

Уральский рабочий. 1918. 17, 19 февр., 7 апр.; 1919. 6, 12 авг.; 1924. 25 мая.

ЦДООСО. Ф. 41. Оп. 1. Д. 126.

Arzel L., Foliard D. Tristes trophées : Objets et restes humains dans les conquêtes coloniales (XIXe - début XXe siècle) // Monde(s). 2020. № 17. P. 9-31.

El Kenz D., Nérard F.-X. Commémorer les victimes en Europe : XVIe-XXIe siècles. Seyssel : Champ Vallon, 2011. 339 p.

Fureix E. La France des larmes : deuils politiques à l'âge romantique (1814-1840). Seyssel : Champ Vallon, 2013. 515 p.

Johnston T. Being Soviet. Identity, Rumour, and Everyday Life under Stalin. Oxford : Oxford Univ. Press, 2011. 240 p.

Koselleck $R$. Les monuments aux morts, lieu de formation de l'identité des survivants : L'expérience de l'histoire. Paris : Hautes Etudes; Gallimard, Le Seuil, 2011. P. 135-160.

Laqueur T. W. The Work of the Dead: A Cultural History of Mortal Remains. Princeton, New Jersey : Princeton Univ. Press, 2015. 711 p.

Nérard F.-X. Détruire les croyances en dévoilant les reliques : un épisode de l'iconoclasme bolchevique après 1917 // Iconoclasme et révolutions de 1789 à nos jours / ed. E. Fureix. Seyssel : Champ Vallon, 2014. P. 222-231.

Nérard F.-X. Of Time and Things: Uses of Objects from Soviet Mass Graves // Les Cahiers Sirice. 2017. Vol. 2. № 19. P. 77-92.

Nora P. Between Memory and History : les lieux de mémoire // Representations. 1989. № 26. P. 7-24. 
Scott J. C. Weapons of the Weak: Everyday Forms of Peasant Resistance. N. Haven : Yale Univ. Press, 1985. 389 p.

Smele J. D. The "Russian" Civil Wars, 1916-1926: Ten Years That Shook the World. Oxford ; N. Y. : Oxford Univ. Press, 2015. 423 p.

Smith S. A. Bones of Contention: Bolsheviks and the Struggle against Relics 1918-1930// Past and Present. 2009. Vol. 204. № 4. P. 155-194. DOI 10.1093/pastj/gtp023.

Traverso E. Mélancolie de gauche : la force d'une tradition cachée (XIXe - XXIe siècle). Paris : La découverte, 2018. 232 p. $348 \mathrm{p}$.

Znamensky P., Gallice G. Sous les plis du drapeau rouge. Paris : Ed. du Rouergue, 2010.

\section{References}

Anichkov, V. P. (1998). Yekaterinburg - Vladivostok (1917-1922) [Yekaterinburg Vladivostok (1917-1922)]. Moscow, Russkii put'. 364 p.

Arzel, L., Foliard, D. (2020). Tristes trophées. Objets et restes humains dans les conquêtes coloniales (XIXe - début XXe siècle). In Monde(s). No. 17, pp. 9-31.

El Kenz, D., Nérard, F.-X. (2011). Commémorer les victimes en Europe : XVIe-XXIe siècles. Seyssel, Champ Vallon. 339 p.

Fureix, E. (2013). La France des larmes : deuils politiques à l'âge romantique (1814-1840). Seyssel, Champ Vallon. 515 p.

Ganin, A. V. (2006). Ataman A. I. Dutov [Ataman A. I. Dutov]. Moscow, Tsentrpoligraf. $622 \mathrm{p}$.

GASO [State Archive of Sverdlovsk Region]. Stock R-511. List 1. Dos. 82, 235.

Iskra [Iskra]. (1865). No. 11.

Johnston, T. (2011). Being Soviet. Identity, Rumour, and Everyday Life under Stalin. Oxford, Oxford Univ. Press. 240 p.

Kamyshlovskie izvestiya [Kamyshlovskie Izvestiya]. (2018). July 26.

Koselleck, R. (2011). Les monuments aux morts, lieu de formation de l'identité des survivants. L'expérience de l'histoire. Paris, Hautes Etudes, Gallimard, Le Seuil, pp. 135-160.

Laqueur, T. W. (2015). The Work of the Dead: A Cultural History of Mortal Remains. Princeton, New Jersey, Princeton Univ. Press. 711 p.

Medvedev, A. I. (1960). Po dolinam i po vzgor'yam [In the Valleys and on the Hills]. Moscow, Voenizdat. $152 \mathrm{p}$.

Medvedev, A. I. (1964). Po dolinam i po vzgor'yam [In the Valleys and on the Hills]. Sverdlovsk, Sredne-Ural'skoe knizhnoe izdatel'stvo. 219 p.

Muzei istorii Ekaterinburga [Museum of the History of Yekaterinburg]. Ed. khr. 1075.

Nérard, F.-X. (2014). Détruire les croyances en dévoilant les reliques : un épisode de l'iconoclasme bolchevique après 1917. In Fureix, E. (Ed.). Iconoclasme et révolutions de 1789 à nos jours. Seyssel, Champ Vallon, pp. 222-231.

Nérard, F.-X. (2017). Of Time and Things: Uses of Objects from Soviet Mass Graves. In Les Cahiers Sirice. Vol. 2. No. 19, pp. 77-92.

Nora, P. (1989). Between Memory and History : les lieux de mémoire. In Representations. No. 26, pp. 7-24.

Scott, J. C. (1985). Weapons of the Weak: Everyday Forms of Peasant Resistance. N. Haven, Yale Univ. Press. 389 p.

Slukhi v Rossii XIX-XX vekov. Neofitsial'naya kommunikatsiya $i$ "krutye povoroty" rossiiskoi istorii [Rumours in Russia in the $19^{\text {th }}-20^{\text {th }}$ Centuries. Non-Official Communication and the "Big Twists" of Russian History]. (2011). Chelyabinsk, Kamennyi poyas. 362 p.

Smele, J. D. (2015). The "Russian" Civil Wars, 1916-1926: Ten Years That Shook the World. Oxford, N. Y., Oxford Univ. Press. 423 p.

Smith, S. A. (2009). Bones of Contention: Bolsheviks and the Struggle against Relics 1918-1930. In Past and Present. Vol. 204. No. 4, pp. 155-194. DOI 10.1093/pastj/gtp023. 
Strod, I. Ya. (1961). Vyakutskoi taige [In the Yakutsk Taiga]. Moscow, Voenizdat. 185 p.

Traverso, E. (2018). Mélancolie de gauche : la force d'une tradition cachée (XIXeXXIe siècle). Paris, La découverte. 232 p.

TSDOOSO [Centre for Documentation of Public Organisations of Sverdlovsk Region]. Stock 41. List 1. Dos. 126.

Ural'skii rabochii [Ural'skii Rabochii]. (1918). Febr. 17, 19; Apr. 7. (1919). Aug. 6, 12. (1924). May 25.

Veber, M. I. (2014). Antibol'shevistskoe povstanchestvo na Urale v gody Grazhdanskoi voiny (1918-1919) [The Antibolshevik Rebellions in the Urals during the Years of the Civil War (1918-1919)]. Dis. ... kand. ist. nauk. Yekaterinburg, S. n. 309 p.

Vlast'naroda [Vlast' Naroda]. (1918). September 1.

Znamensky, P., Gallice, G. (2010). Sous les plis du drapeau rouge. Paris, Ed. du Rouergue. 348 p.

The article was submitted on 29.09.2020 